Journal of Yaşar University

http://journal .yasar.edu.tr

Journal of Yasar University 2014 9(33) 5649-5673

\title{
ESTIMATION OF THE COSTS OF TRAFFIC ACCIDENTS IN TURKEY: AN EVALUATION IN TERMS OF THE INSURANCE AND FINANCIAL SYSTEM*
}

\section{TÜRKIYE'DE TRAFIK KAZASI MALIYETLERININ TAHMINI: SIGORTACILIK VE FINANSAL SISTEM AÇISINDAN BIR DEĞERLENDIRME}

\author{
Ercan ÖZEN ${ }^{1}$ \\ Erhan GENÇ \\ Zübeyde KAYA ${ }^{3}$
}

\section{ABSTRACT}

The aim of the study is to estimate the costs of traffic accidents in Turkey and to put forward conjectural magnitude of these costs within insurance and financial system. Another purpose is to predict the non-systemic costs which are difficult to be involved in records and that are caused by accidents.

Different kinds of cost elements come out as a result of traffic accidents. In this study, great effort is spent to predict the cost elements such as material damage, medical care and labour loss. The cost predictions are performed by using the data issued by Turkish Insurance Association and the data acquired by the questionnaire carried out in the city of Uşak. In cost analysis conducted, it is seen that the total costs of traffic accidents occurred in 2012 is more than $\$ 4,3$ billion. It is found out that insurance companies made a loss of approximately $\$ 233$ million from traffic insurance operations in 2012. This decreases the contribution of insurance companies, which have significant

\footnotetext{
* This article was funded by Uşak University Scientific Research Project Unit, Project No: 2013-SOSB005

1 ercan.ozen@usak.edu.tr, eozentr@hotmail.com, Assistant Professor in Uşak University Applied Sciences Academy Banking And Finance Department

2 erhan.genc@usak.edu.tr, Research Associate in Uşak University at Faculty of Economics and Administrative Sciences Department of Business

${ }^{3}$ zkaya64@ @otmail.com Afyon Kocatepe University SSI. Postgraduate at Business Department
} 
function in financial system, to total saving volume. The total accident costs found in this study accounts for $16,37 \%$ share within insurance system, $0,36 \%$ share within financial system and $0,55 \%$ share within GDP.

Key Words $\quad$ : Costs of traffic accidents, Insurance, Finance, GDP

Jel Codes : G21, G22, O16, R41, R42

\section{ÖZET}

Çalışmanın amacı, Türkiye'de trafik kazalarının maliyetlerini tahmin etmek ve bu maliyetlerin sigortacılık ve finansal sistem içindeki tahmini büyüklüğünü ortaya koymaktır. Çalışmanın diğer bir amacı da, kayıtlara dahil edilmesi oldukça zor olan, kazalardan doğan sistem dışı maliyetleri tahmin etmektir.

Trafik kazalarına bağlı farklı maliyet unsurları ortaya çıkabilmektedir. Çalışmada; maddi hasara, tedavi ve işgücü kaybına bağı maliyet unsurları tahmin edilmeye çalışılmıştır. Maliyet tahminleri Türkiye Sigorta Birliği tarafından yayınlanan veriler ve Uşak ilinde uygulanan anket çalışmasından elde edilen veriler kullanılarak yapılmıştır. Yapılan maliyet hesaplamalarında, 2012 yılında trafik kazalarının toplam maliyetinin 4,3 Milyar ABD Doları́nın üzerinde olduğu tahmin edilmiştir. Sigorta şirketlerinin trafikle ilgili sigorta işlemlerinden 2012 yılında yaklaşık 233 Milyon \$ tutarında zarar ettikleri görülmüştür. Bu da finansal sistem içinde önemli fonksiyona sahip olan sigorta şirketlerinin, toplam tasarruf hacmine yaptığı katkıyı azaltmaktadır. Çalışmada bulunan kaza maliyetlerinin toplamı, sigortacılıkta $\% 16,37^{\prime}$ lik paya, finansal sistem içinde $\% 0,36^{\prime}$ lik paya sahipken, GSYiH içinde $\% 0,55^{\prime}$ lik paya sahiptir.

Anahtar Kelimeler : Trafik Kaza Maliyeti, Sigorta, Finans, GSYiH

Jel Kodları : : $\quad$ 21, G22, O16, R41, R42 


\section{1-INTRODUCTION}

Transport is one of the crucial matters of our life and our age. People carry out their transport by road, railway, airway and seaway. Of all the transport systems, road is by far the most used transport system. Road transport obviously has many advantages for both individuals and countries. By means of road transport, countries improve their growth thus individuals can easily have access to education and health services. Moreover, both domestic and overseas mobilization of humans and goods are made easy via road transport (Watkins and Sridhar, 2009: 4). This mobilization has a crucial role in bringing competitiveness to market economy. However; the accidents related to transport and shipping bear considerable cost risks at micro and macro level. While road traffic accidents, in micro scale, cause significant costs in human life, in macro scale, they inflict immense costs on nations' economies.

As far as 2013 report of World Health Organization (WHO, 2013b: 1) is concerned, nearly 1,24 million people have lost their lives and roughly 20 to 50 million people get injured as a result of these road accidents. In addition to adverse affects of road traffic accidents on individual lives, the accidents lead to dramatic financing costs especially for developing countries. It 's estimated that the costs of traffic accidents having occurred in countries with low and mid income account for about $1 \%$ to $3 \%$ of GNP, This fact indicates how substantial cost road traffic accidents inflict on national economies.

In Turkey, Road is the most widely used means of transport both in terms of passenger and goods transport. More than $\% 90$ of all the transportation activities have been taking place via road. As seen in all over the world, so is in Turkey, road traffic accidents are among the ones that leads to death. The fact that road transportation is dense and its being one of the leading cause of deaths in traffic accidents are evaluated as a significant cost element wit respect to national economy (Öztürk and Eken, 2006: 12-13).

The decision-makers in economics have to take all cost elements into consideration. Therefore, that the costs caused by traffic accidents, after being determined, is to be presented to the decision-makers will be important in improving the profitability and efficiency of investments. Discounting individual-based micro costs, the most important cost of traffic accidents takes place on insurance companies. This cost element reducing the profitability has negative effect on such functions of insurance companies as risk-management and saving extension.

It is necessary for insurance companies to create a reserve in order to be able to compensate insurance recovery demands likely to exist in the future. These reserves are used for financing real investments (Ünal, 1994: 21). Reserve funds acquired by insurance companies increases the volume 
of savings in financial system. The fact that the funds collected as savings are transformed into efficient investments creates a triggering effect on total production strength and on economic growth. From this aspect, insurance companies take on the task of financial intermediation in financial system.

Amount of premiums gained in 2012 in insurance system happened to be at a level of 19,8 billion TRL (\$11 billion) and contributed to saving volume (Sigortacl Gazetesi, 2013). Premium production being $\$ 40$ quota per capita in the year 2000 also rose at a level of $\$ 144$ (TSB, 2012:6). These values have indicated that the contribution insurance system has made to financial markets is increasingly going on. However; fund outflows related to pay damages implemented depending on traffic accidents cause fund supply to remain limited. In other words, macro economical effects of costs caused by traffic accidents cause insurance companies' function of fund-raising for financial markets to reduce.

It has been reported that insurance companies have made a loss in insurance branches related to traffic in Turkey and in the World. Insurance companies try to compensate these loses with their investment incomes. Insurance companies in Turkey have made serious amounts of loses from traffic insurances both because of claim payments and intense competition between these companies (Özer, 2010).

The search, in order to create a social awareness on reducing the number of traffic accidents, is a part of 'Uşak Road Traffic Festival' (http://trafikfestivali.usak.edu.tr) organized under the lead of Uşak University and is consisted of two basic dimensions. Primarily, in this search, the costs traffic accidents caused will be calculated for Turkey, taking City of Uşak as the starting point. With a general look, the costs such as material damage and treatment emerge as a result of traffic accidents and also their amounts can be calculated depending on official records. Nevertheless; it is impossible to determine financial sums paid by individuals owing to some damages and injuries. On the other hand; victims can remain separate from their work. As a consequence of this, the existing cost of labour loss can't be calculated, either. At the first stage of our study, the aim is to calculate these costs mentioned above. At the second stage, however, how much affect the costs caused by traffic accidents have on insurance system, financial system and on GDP has been evaluated.

The general calculation of the costs of traffic accidents is carried out by using official data. It is possible to observe the examples of those data in the studies of Elvik (1995), Elvik (2000), Connelly and Supangan (2006), Pérez and Garcia (2007) and Al-Masaeid et al. (1999). Besides official data, it is seen that accident predictions are also conducted via electronic survey method (Aertsens et al., 2010). Furthermore, as witnessed in the studies of Reeddy et al. (2009), Hejazi et al. (2013), Seninger 
(2010), like local based traffic costs, city-based cost determining efforts have been made. In determining the costs of traffic accidents, while official data are used in some studies, in the other studies survey method is used. However, in almost none of these studies, official data and survey method are used simultaneously and they are kept separate in terms of cost elements involved.

In this study, in addition to the costs calculated with respect to formal statistical data, damage loses, treatment loses and labour loses obtained by survey method are involved in calculation of the costs of traffic accidents. The most important elements of this study from this perspective are that the costs of damage loses, treatment loses and labour loses that can't be seen in official records were attempted to be calculated by using survey data, that the costs of traffic accidents in Turkey in the year 2012 were predicted with the help of some predictions and that these predicted sums were compared with significant financial indicators.

2- AN EVALUATION OF ROAD TRAFFIC ACCIDENTS IN TURKEY AND AN ASSESSMENT OF THEIR COSTS

Table-1: Statistics of Traffic Accidents in Turkey

\begin{tabular}{|c|c|c|c|c|}
\hline Years & Number of Vehicles & Accidents & Deaths & Injuries \\
\hline 1990 & 3750678 & 115295 & 6317 & 87668 \\
\hline 1991 & 4101975 & 142145 & 6231 & 90520 \\
\hline 1992 & 4584717 & 171741 & 6214 & 94820 \\
\hline 1993 & 5250622 & 208823 & 6457 & 104330 \\
\hline 1994 & 5606712 & 233803 & 5942 & 104717 \\
\hline 1995 & 5922859 & 279663 & 6004 & 114319 \\
\hline 1996 & 6305707 & 344643 & 5428 & 104599 \\
\hline 1997 & 6863462 & 387533 & 5125 & 106246 \\
\hline 1998 & 7371541 & 458661 & 6083 & 125793 \\
\hline 1999 & 7758511 & 465915 & 5713 & 125158 \\
\hline 2000 & 8320449 & 500664 & 5510 & 136751 \\
\hline 2001 & 8521956 & 442960 & 4386 & 116203 \\
\hline 2002 & 8655170 & 439777 & 4093 & 116412 \\
\hline 2003 & 8903843 & 455637 & 3946 & 118214 \\
\hline 2004 & 10236357 & 537352 & 4427 & 136437 \\
\hline 2005 & 11145826 & 620789 & 4505 & 154086 \\
\hline 2006 & 12227393 & 728755 & 4633 & 169080 \\
\hline 2007 & 13022945 & 825561 & 5007 & 189057 \\
\hline 2008 & 13765395 & 950120 & 4236 & 184468 \\
\hline 2009 & 14316700 & 1053346 & 4324 & 201380 \\
\hline 2010 & 15095603 & 1106201 & 4045 & 211496 \\
\hline 2011 & 16089528 & 1228928 & 3835 & 238074 \\
\hline 2012 & 17033413 & 1296636 & 3750 & 268102 \\
\hline Average & 9341363 & 482958 & 5033 & 156431 \\
\hline
\end{tabular}

Source: www.tuik.gov.tr, www. trafik.gov.tr, The values above shows a total data gathered from police and gendarme regions 
Road traffic density, violating traffic rules, lack of traffic safety in Turkey cause traffic accidents to increase further. As a result of these accidents, there emerge deaths, injuries, disabilities and great amounts of economical loss (TUiK, 2011: 3). Table 1 can give us a general assessment of traffic accidents occurred in Turkey. When Table-1 is observed, it is seen that there was a rise in the number of cars registered to traffic and in the number of traffic accident cases between the years of 1990-2012. Moreover, it is seen that in traffic accidents, average 5.033 people lost their lives and 156.431 people were injured in a year.

Table-2: Indications of Accidents per Vehicle in European Countries (2008)

\begin{tabular}{|l|r|r|r|r|r|}
\hline Country & \multicolumn{1}{|c|}{$\begin{array}{c}\text { Vehicle Per } \\
\text { Capita }\end{array}$} & \multicolumn{1}{c|}{$\begin{array}{c}\text { Number Of } \\
\text { Vehicles }\end{array}$} & $\begin{array}{c}\text { Rate of } \\
\text { Accidents per } \\
\text { Vehicle \% }\end{array}$ & $\begin{array}{c}\text { Rate of Deaths } \\
\text { per Vehicle \% }\end{array}$ & $\begin{array}{c}\text { Rate of Casualties } \\
\text { per Vehicle \% }\end{array}$ \\
\hline Belgium & 0,558 & 5.976 .180 & 0,705 & 0,016 & 1,078 \\
\hline Denmark & 0,549 & 3.016 .206 & 0,166 & 0,013 & 0,196 \\
\hline Germany & 0,634 & 52.057 .740 & 0,616 & 0,009 & 0,786 \\
\hline Greece & 0,451 & 5.067 .887 & 0,298 & 0,031 & 0,375 \\
\hline Spain & 0,608 & 27.698 .048 & 0,336 & 0,011 & 0,473 \\
\hline France & 0,575 & 36.906 .950 & 0,202 & 0,012 & 0,254 \\
\hline Irland & 0,542 & 2.398 .892 & 0,281 & 0,012 & 0,406 \\
\hline Italy & 0,690 & 41.284 .080 & 0,530 & 0,011 & 0,753 \\
\hline Luksemburg & 0,749 & 366.261 & 0,253 & 0,010 & 0,338 \\
\hline Holland & 0,523 & 8.601 .258 & 0,276 & 0,008 & 0,320 \\
\hline Austria & 0,561 & 4.677 .057 & 0,838 & 0,015 & 1,080 \\
\hline Portugal & 0,537 & 5.704 .014 & 0,589 & 0,016 & 0,768 \\
\hline Finland & 0,591 & 3.139 .983 & 0,219 & 0,011 & 0,271 \\
\hline Sweden & 0,522 & 4.812 .840 & 0,384 & 0,008 & 0,545 \\
\hline England & 0,525 & 32.231 .850 & 0,549 & 0,008 & 0,738 \\
\hline Czech Republic & 0,485 & 5.055 .640 & 0,445 & 0,021 & 0,564 \\
\hline Estonia & 0,474 & 635.634 & 0,294 & 0,021 & 0,377 \\
\hline Latvia & 0,459 & 1.040 .094 & 0,403 & 0,030 & 0,520 \\
\hline Lithuania & 0,555 & 1.863 .690 & 0,263 & 0,027 & 0,312 \\
\hline Hungary & 0,301 & 3.021 .438 & 0,635 & 0,033 & 0,840 \\
\hline Malta & 0,743 & 306.116 & 0,250 & 0,003 & 0,281 \\
\hline Poland & 0,508 & 19.368 .008 & 0,253 & 0,028 & 0,321 \\
\hline Slovenia & 0,566 & 1.143 .886 & 0,801 & 0,019 & 1,114 \\
\hline Slovakia & 0,348 & 1.881 .636 & 0,443 & 0,032 & 0,579 \\
\hline Bulgaria & 0,375 & 2.858 .625 & 0,281 & 0,037 & 0,348 \\
\hline Southern Cyprus & 0,659 & 522.587 & 0,266 & 0,016 & 0,376 \\
\hline Norway & 0,578 & 2.755 .904 & 0,280 & 0,009 & 0,394 \\
\hline Romania & 0,230 & 4.948 .220 & 0,592 & 0,062 & 0,731 \\
\hline Turkey & 0,192 & 13.641 .984 & 0,764 & 031 & \\
\hline & & & & & \\
\hline
\end{tabular}

Source: TUik 2012, s.7 ve www.wikipedia.com are used and the data are calculated by the searcher 
When Table-2, in which accident rates per vehicle in European countries are indicated, is examined, Turkey ranks third with a 0,764 rate of accident per vehicle, ranks fourth with a 0,031 rate of death per vehicle and ranks first with a 1352 rate of injury per vehicle. When the statistics are evaluated generally, it is clear that Turkey has much higher values than European countries in terms of traffic accidents statistics. This kind of statistics is also released by TUiK (2012). However; as can be seen in our study, using car-possession rates instead of population rates will help carry out better analysis for Turkey where car-possession-rate is relatively lower.

Results of the report about traffic safety prepared by General Directorate of Highways in 2001, clearly states that the death rate in turkey, when the number of vehicles and the amount of road covered are taken into account, is nearly 14 times higher than the average of European countries (Sümer et al., 2002:1). This fact shows that Turkey among European countries is one of the countries in which traffic accidents are the most prevalent.

Traffic accidents impose heavy costs on national economies in many ways. Determining these costs of the traffic accidents is crucial economically in that decision makers are able to reach a conclusion about the solution. The number of issued articles about the costs of traffic accidents is fairly little.

\section{3-LITERATURE}

Costs of traffic accidents are made up of several different factors combined and classified into several forms. The most common classification is the distinction between direct cost and indirect cost (Hejazi et al., 2013; Elvik, 1995; Elvik, 2000; Travén et al., 2002). Direct costs include funeral and medical costs caused by deaths or physical injuries, economical loses, time loss and management expenses. It is very difficult to determine these costs, though. Economic loss can take place on such elements as the vehicle, the road and traffic lights and barrier. It is impossible to determine the costs caused by time loss, as well. Determining the most accurate costs require employing several human and data. Indirect losses are comprised of productivity and efficiency loss, life loss, permanent disabling, physiological damages and socio-economic losses. Furthermore; a compensation money called ' blood money'(Hejazi et al., 2013) ,exercised in such countries as Korea, Japan, Turkey and Iran, is paid to kith and kin of a person killed in an accident by the kith and kin of the person who has lead to the accident.

Anh and Dao (2005), in their study, divided the costs of road traffic accidents into two groups as tangible and intangible costs of accidents and also collected tangible costs of accidents in themselves under three headings as vehicle-damage costs, medical costs and the costs tolerated in order for police and emergency services crews to be able to reach to the accident scene during 
accident. On the other hand, they divided intangible costs of accidents into two categories. One of them is the time individuals involved spend in hospital or individuals' incapacity costs as a result of accident involving injury. The other is human cost.

Many costs of traffic accidents are registered in the national account of the countries (Elvik, 2000: 850). The losses in standard of living on the individual and national basis as nonmarketable securities can't be reflected on national accounts because they don't possess economic value.

The studies on accounting the costs of traffic accidents are fairly few in number in Turkey. In foreign literature, however, there are much more studies than the ones in Turkey. One of the first studies conducted in Turkey on the costs of traffic accidents is the study carried out by DirectorateGeneral Traffic with the aim of determining the costs of traffic accidents occurred in 1998. According to this study, the amount of the costs of accidents in Turkey is calculated as TRL 2,8 billion and its ratio to national income is calculated as 2,2\% (Elmas and Yıldızhan, 1999).

Road Improvement and Traffic Safety Project (RITSP) financed partially by IMF loans and partially by Turkish Government in the years 1999-2000 aimed to prepare a strategy and an action plan, to develop a vision and to investigate traffic safety problem (Sweroad, 2001). In this study, the costs of traffic accidents were estimated as 2 billion together with that of 1999. It is projected that when it comes to 2011, the costs would reach TRL 2,9 billion together with the costs of 1999. While getting the values related to the costs of accidents in Turkey, any chance of comparing the acquired values annually doesn't exist because any method of creating the values aren't applied. In addition, World Health Organisation (WHO, 2013a), pointed out that there were few studies on determining the costs of traffic accidents and estimated that global costs of traffic accidents reached $\$ 518$ billion. Some of the studies in which the costs of traffic accidents are calculated are mentioned below. Anh and Dao (2005), in their study, attempted to figure out the costs of traffic accidents occurred in Vietnam. To achieve this goal, they studied traffic accidents and their costs occurred in the years 2002, 2003 and 2004 and then they found the costs of accidents as 13.153.000, 11.034.000 and 10.051.604 Vietnam Dong (VND) respectively. Also in another study on Vietnam, Nguyen vd. (2013), analyzed the values of 470 accidents involving personal injuries accepted in a hospital and it was found that these accidents resulted in $\$ 363$ of direct and indirect medical expenses per capita and was also reported that the motorcyclists not wearing helmets accounted for $41 \%$ higher costs than the others.

Elvik (1995), in his study, comparatively analyzed the costs of traffic accidents occurred in 20 countries. He found that the cost of accidents involving deaths was between 0.87 and 17,80 million Norwegian Crone. Average cost value was calculated as 5,69 Norwegian Crone. In his another study, 
Elvik (2000) tried to determine what the equivalent of the costs of traffic accidents was in GDP. Accordingly, easily accessible formal averages of the costs of traffic accidents in 12 countries in 1990 or onwards were collected and proportioned to nations' average GDP. As a result, the costs of traffic accidents occurred in Spain in 1997, (López et al., 2004), was calculated as €172,38 per capita because of medical care, insurance operations, physical damage, short term and permanent disablement. And the ratio of all costs of traffic accidents to national income is determined as 1,35\%. Moreover, Alemany et al. (2013) also stated that the ratio of the medical and rehabilitation costs of injured people involved in traffic accidents occurred in Spain in 2008 to national income was calculated as \% 0,04. In the study of Ñuñez-Péréz, et al.,(2010) where economical effects of accidents involving deaths and personal injuries occurred in Belize on 2007 it was detected that 61 people passed away, 338 people were hospitalized and 565 people were slightly wounded. The deaths occurred made estimated 2.501 years lost out of potential lifespan, which resulted in $\$ 11.062 .544$ of financial cost in total. The ratio of this cost to GDP of Belize was calculated as $0,9 \%$. Total direct cost elements were also calculated as $\$ 163.503$. In the study of Antić et al. (2011) in which the costs of traffic accidents occurred in Serbia were analyzed, the cost of traffic accidents in 2003 was €256 million, while in 2009 the cost reached $€ 532$ million. The ratio of this cost to national income was calculated as $1,6 \%$.

Connelly and Supangan (2006) attempted to determine in their study the financial costs of road traffic accidents occurred in Australia and in its neighbourhood. They stated that annual cost caused by traffic accidents in 2003 was $\$ 17$ billion and this cost was equivalent to $2,3 \%$ of GDP. Pārupa and Ādamsone (2008) pointed out in their study, where they analyzed the costs of precautions aimed to reduce the rate of traffic accidents in Lithuania, that the costs of accidents which was \$217 million in 2006 accounted for 1,55\% rate of Gross National Domestic Product. Pérez and Garcia (2007) tried to determine the costs of traffic accidents occurred in Barcelona in 2003. According to outcomes of the study, direct costs including vehicle damage costs, insurance costs and costs of medical expenses were $€ 367$ million (accounts for 89,92 percent of total costs), whereas indirect costs including cost of labour force lost as a result of deaths and injuries were around $€ 37$ million.

İsmail and Abdelmageed (2010) investigated cost of road traffic accidents in 2008 in Egypt and found that estimated cost of traffic accidents was roughly 10 million Egyptian Pound (about $\$ 1,8$ billion).

With the method of electronic survey including 1187 people, Aertsens et al. (2010) calculated the total direct and indirect costs of emerging losses per victim caused by cyclist accidents in Belgium. Veisten et al. (2007), who aimed to determine the cost of cyclist injuries occurred in 
Norway, estimated the annual financial cost of cycling injuries as $€ 300$ million and pointed out that these costs accounted for nearly half of total accounts of private sector, public sector and financial accounts and then emphasized the size of acquired amount.

(Reeddy et al, 2009), in their study conducted in the city of Chandigarh, India, according to the results of the survey carried out with 95 injured people in an accident occurred in 2004, calculated the total loss as $\$ 1,9$ million caused by injuries, pecuniary loss and production loss in these accidents and as 20.048 \$ per accident. Hejazi et al. (2013) estimated direct and indirect costs of accidents occurred in the city of Mazandaran, Iran, in 2007 by examining registers of the police records, records of insurance companies and medical records. As a result, it was indicated that the costs of accidents emerging in 2007 was around \$2,2 million. Seninger (2010) pointed out that, as a result of the accidents involving alcohol use in Montana, USA, loss valued at annual $\$ 642$ million was experienced due to medical costs, labour loss and efficiency loss.

Al-Masaeid et al. (1999) aimed to determine the costs of traffic accidents occurred in Jordan in 1996. In classifying the costs of accidents, the costs such as pecuniary damage losses, insurance costs, medical costs, vehicle repair costs were employed in the study and the total cost of traffic accidents in Jordan was identified as $\$ 103$ million. Zaloshnja et al. (2006) aimed to reveal the costs of traffic accidents in USA in terms of the way the accidents happened. Consequently, stating that the highest cost of all accidents was caused by head on crash with a speed of $50 \mathrm{Mph}$ or over and by a vehicle's running over a pedestrian, he calculated the costs per accident as 1,69 and \$1,16 million successively.

Maraste et al. (2003) aimed to estimate the costs caused by the injuries occurred as a result of traffic accidents in Sweden. As study results indicated, they predicted average medical expenses to be 46,200 SEK (by the figures in 1995). However, these costs didn't comprise permanent disability, therefore, when these costs were re-calculated by using average lifespan, medical costs turned out to be 100,300 SEK.

Caliendo and De Guglielmo (2012) aimed to determine the costs of traffic accidents in subways of Italy and their social costs. 762 accidents occurred in 195 subways between the years 2006 and 2009 were observed and as a result of these accidents, 774 people were injured and 18 people passed away. It is reported that the accidents occurred in subways between 2006 and 2009 were higher than those in highways and the costs of these accidents varied from $€ 12.46$ to $€ 284.72 / 1000$ $\mathrm{km}$. Elvik et al. (2009), by conducting cost benefit analysis, made benefit analysis acquired as a response to costs suffered at the expenses spent for the sake of preventing traffic accidents. Analyze results indicated that the costs suffered were calculated as 10.361 million SEK(Swedish Crone) and 
the benefit acquired as 10.614 million SEK(Swedish Crone). Based on these search results, the costs incurred as a result of expenses and investments carried out for the sake of preventing traffic accidents will be lower than the benefits acquired (social and financial costs diminishing as a result of reducing traffic accidents) and thus investments aiming to prevent traffic accidents should be given priority. Traffic accidents, on the other hand, have considerable negative effects on financial structures of insurance system. There aren't so many studies investigating this issue.

However, Doğan (2013) indicated that high loss ratio of insurance companies has adverse affects on firms' profits significantly. Damage payments related to traffic accidents increase the total payments of insurance companies and thus the debts of firms increase due to the fact that such payments boost financial needs. These factors affect adversely profit rates of insurance companies. Al-Shami (2008) and Malik (2011) also indicated that, as Doğan (2013) did, damage payments had an adverse affect on profits of firms. Yıldırım (2013) emphasized that insurance companies were adversely affected owing to traffic accidents and these effect got deeper because of such reasons as false accident reports and so on.

\section{METHOD}

In this study, the starting point is a questionnaire conducted in city of Uşak on calculating the costs of traffic accidents. The data has been collected by face-to-face interview method with 506 people during April 2013. This questionnaire not only aims to measure the perception levels of people residing in Uşak regarding traffic accidents but also to obtain data supposed to help calculate the costs of traffic accidents falling outside the system. The data about measuring perception levels are excluded in this study. The questionnaire also includes the accidents occurred in the first four months of 2013. All the accidents occurred in Uşak in a one-year period from April and backwards are accepted as if occurred in the year 2012. This acceptance is the first assumption of this study.

Costs of accidents falling out of the system are calculated in two stages. In the first stage, people involving in the accidents are asked about how they paid in case of damage and injury following the accident. The fact that damages are made up for by automobile insurance, compulsory traffic insurance or by accident victims themselves comes out as a result. Damage costs and medical costs are paid by accident victims themselves because of some reasons. In the second stage, the goal is to determine labour losses caused by traffic accidents. So as to find out the value of labour losses, accident victims are asked about how much time they had to get apart from their professions after the accident. Based on this fact, time equivalent of labour loss is found out. In order to calculate financial equivalent of this time, average income levels of respondents are used as data. Financial equivalent of workforce is calculated by using monthly revenue amounts and daily equivalent of 
labour loss. Data acquired from questionnaire is combined with the data of General Directorate of Security (SGK), Insurance Association of Turkey (TSB) and of Turkish Statistical Institute (TUiK). Starting from this, the costs of traffic accidents are estimated in a way comprising the ones falling out of the system.

This study consists two main extents. Initially, the costs caused by traffic accidents are calculated for Turkey by taking Uşak as the starting point. Although most of material damages and medical costs are reflected in official records, some of these expenses can fall out of system. In the study, such kind of non-system costs and costs caused by labour loss are going to be determined depending on the search conducted in Uşak.

Because of the difficulty in getting sample survey to reflect Turkey-wide, the data acquired by survey method is used in Uşak. Non-system costs of traffic accidents calculated for Uşak, in accordance with this assumption, are multiplied with the number of all traffic accidents occurred in Turkey by generalizing, and total non-system costs of traffic accidents are calculated conjecturally.

When viewed generally, as a result of an accident, costs such as material damage and medical costs come out and their amounts can be calculated depending on official records. But, after accident, it is impossible to determine financial costs paid by individuals themselves due to damage or injury. On the other hand; accident victims aren't able to keep to their professions because of accident. As a result of this, the cost of resulting labour loss can't be calculated, either. This study aims to calculate all these costs. And in the latter part of the study, the costs caused by traffic accidents and the costs paid by insurance companies and their place within the insurance sector and financial system are going to be evaluated.

\section{FINDINGS}

Findings of the study are handled in two parts. In the first part, with the contribution of data acquired with questionnaire carried out in Uşak province, the costs of traffic accidents not reflected in official records have been analogically determined for Turkey.

In the other part, data of governmental agency regarding the costs of traffic accidents is compiled and then macro-size of total accident costs acquired with both methods mentioned above have been determined.

\subsection{Direct and Indirect Costs Acquired with Questionnaire Conducted in Uşak}

Accident costs based on the data of questionnaire carried out in Uşak are determined in three stages. In the first stage are the amounts paid by both sides if there is a vehicle involving the accident and other party. The second cost includes amounts paid by both parties for medical care. 
Finally, labour loss caused by the accident is determined and the costs of labour loss are calculated by relating them with incomes.

Accident and medical costs are expressed as directly- measured costs, labour loss costs, however, are expressed as indirectly-measured costs.

\subsubsection{Accident Burning Cost}

73 out of 506 test subjects said that they had an accident within a year. Test subjects were asked about how the damages, if any, on both cars were met and how much was paid. In 29 out of 73 traffic accidents occurred in the last one year period, pay-damages application wasn't presented to motor insurance or compulsory traffic insurance and the damages were met by accident victims. 3 test subject haven't stated his or her opinion about the way how he or she paid for damages. Accordingly, nearly 40 percent of traffic accidents weren't recorded in the system. So, there wasn't any official data concerning the repair and medical costs paid by these unrecorded individuals. In Table- 3 and Table- 4 , how the damages of parties involving the accidents are met can be observed.

Table-3: Who Paid the Damage of Owned Car

\begin{tabular}{|l|c|c|}
\hline Who Paid the Damage of Your Car & Number of People & Ratio \% \\
\hline Motor Insurance & 26 & $37,1 \%$ \\
\hline Traffic Insurance & 15 & $21,4 \%$ \\
\hline Myself & 23 & $32,9 \%$ \\
\hline Other Party & 6 & $8,6 \%$ \\
\hline Total & 70 & $100,0 \%$ \\
\hline
\end{tabular}

According to Table-3, 58 percent of all damages were met by motor insurance and traffic insurance

Table-4: Who Paid the Damage of Other Party

\begin{tabular}{|c|c|c|}
\hline Who paid, if any, the damage of Other Party & Number of People & Ratio \% \\
\hline Motor Insurance & 25 & $42,4 \%$ \\
\hline Traffic Insurance & 11 & $18,6 \%$ \\
\hline Myself & 7 & $11,9 \%$ \\
\hline Other Party Himself & 16 & $27,1 \%$ \\
\hline Total & 59 & $100,0 \%$ \\
\hline
\end{tabular}

According to Table-4, 61 percent of the damages belonging to other party was paid by motor insurance or traffic insurance.

When the data in Table- 3 and Table- 4 are examined together, by simple average, total damage payment rate through motor insurance for both parties is $39,75 \%$, through traffic insurance is $20 \%$. Based on this data, 59,75 percent of all accidents are paid through insurance. The rest 40,25 percent of the damage are paid by accident victims themselves. 
Accordingly, In each accident occurring in Uşak, nearly 40 percent of damage payments were met by accident victims themselves.

Some vehicles may not have traffic insurance or motor insurance contract. Even though accident insurance contract are taken out, small-scale damages may not be reported to insurance companies in order for no-claim discount not to be terminated.

In questionnaire, the drivers involving in the accident were asked about how much money they themselves paid for the damage of their own vehicle. 29 drivers declared that they themselves paid Turkish Lira (TRL) 25.180 for the damage of their own vehicle caused by either themselves or other parties without applying to insurance agency. Accordingly, the average damage cost paid for their own vehicles was calculated as TRL899,28.

Two vehicles may be involved in the accident simultaneously. When how much money was paid for other party's vehicle apart from insurance was asked, the average cost amount came out as TRL1,375.

The total financial payment for vehicles of both parties was found to be TRL33.430 and then total damage cost per accident paid by accident victims themselves was determined as TRL1.152,75.

According to 2012 TUIK data, 1.296 .636 accidents occurred in Turkey. In 40 percent of these accidents, damage payments fell out of the system according to the data our study provided. That is to say, in $1.296 .636 \% 40=518.654$ accidents, payment fell out of system. Therefore, 518.654 *1.152,75= TRL597.489.870 (\$331.728.720) which accounts for material damage payment not reflected on the system were calculated.

\subsubsection{Medical Cost}

15,07 TL medical payment for per accident were paid. The reason why such a little amount comes out is the fact that the large proportion of the total population is under medical insurance. In 1.296.636 accidents occurred in Turkey in the year 2012, total medical care spending is calculated as 19.540.305 TL (10.848.854 US Dollar).

\subsubsection{Labour Loss Cost}

In the event of employees having an accident, they may get apart from their professions due to medical care excuses and so on. In this case, SGK( Social Security Organization) or any related organization pays a price for the ones involving in the accident. This price is also evaluated as labour loss. In calculating this price of labour cost in question, two tables below indicating the incomes and periods in which victims were kept away from their jobs were exploited. 
Table- 5: Average Income

\begin{tabular}{|l|c|c|}
\hline Monthly Income (TRL) & Number of People & Ratio \% \\
\hline $\mathbf{0 - 7 5 0}$ & 118 & 23,40 \\
\hline $\mathbf{7 5 1 - 1 . 5 0 0}$ & 184 & 36,40 \\
\hline $\mathbf{1 . 5 0 1 - 2 . 2 5 0}$ & 103 & 20,40 \\
\hline $\mathbf{2 . 2 5 1 - 3 . 0 0 0}$ & 49 & 9,70 \\
\hline $\mathbf{3 . 0 0 1 +}$ & 51 & 10,10 \\
\hline Total & 505 & 100.00 \\
\hline
\end{tabular}

According to Table-5, average income is calculated as TRL1.488,11.

Table-6: Duration in Which Employees Were Kept From Their Jobs Due to Accident

\begin{tabular}{|l|c|c|}
\hline Duration of Kept away From Job & Frequency & Ratio \% \\
\hline Less than one day & 17 & 23,20 \\
\hline Between 1-7 days & 2 & 2,80 \\
\hline Between 8-30 days & 15 & 20,50 \\
\hline More than one month & 15 & 20,50 \\
\hline Permanent & 7 & 9,60 \\
\hline Never kept away from job & 17 & 23,20 \\
\hline Total & 73 & 100.00 \\
\hline
\end{tabular}

According to the results of the questionnaire, it was calculated that accident victims were kept away from their jobs for 7.332 hours. While calculating these hours, seven people having permanent disablement were excluded from calculations in Table-6. This time period, when 73 traffic accidents are taken into consideration, has come up as 12,55 daily labour loss per accident.

When the average monthly income of respondents are found to be TRL1.488,11, the financial equivalent of 12,55 daily labour loss are calculated as TRL889,26.

Those who acquired permanent disablement are retired due to disability by Social Security System and begin to receive a pension. It is assumed that pension contributions of these people are calculated by rock bottom. In the second period of 2012, subsistence wage was TRL739,80. When these people complete their 1800-day insurance period, in the event of disablement, they deserve to get the 40 percent of their wages whose statement is registered in insurance records. Besides the annual costs of getting retired due to disability, all those retired due to disability as a result of traffic accidents are assumed to provide such conditions as minimum duration, wage and so on required by law. As a consequence, without becoming older age pensioner and without any paid employment, it may be reckoned that they are paid at least TRL295,60 dead monthly wage. This amount can also be evaluated as a cost caused after the traffic accident. In this case, owing to those retired due to disability caused by traffic accidents, TRL340,14 accident cost per accident is estimated for all the accidents occurred in one year period. 
Consequently, when retired people due to disability living in Uşak are also included, conjecturally TRL1.229,40 labour losses per accident come up. According to TUIK's data, the number of accidents occurred in Turkey-wide is 1.296.636. When the number of accidents are multiplied with monetary value of labour loss per accident, the monetary value of total labour loss caused by accidents occurred in Turkey is TRL1.594.084.300. This value accounts for $\$ 885.041 .860$ when calculated with the average exchange of Central Bank of the Republic of Turkey (TCMB).

Table-7: Traffic Accidents Costs Searched Out Within the Questionnaire

\begin{tabular}{|c|l|r|r|r|}
\hline Currency & \multicolumn{1}{|l|}{$\begin{array}{l}\text { Material } \\
\text { Damage }\end{array}$} & Medical Care & \multicolumn{1}{c|}{ Labour Loss } & \multicolumn{1}{c|}{ Total } \\
\hline TRL & 597.489 .870 & 19.540 .305 & 1.594 .084 .300 & 2.211 .114 .475 \\
\hline $\mathbf{S}$ & 331.728 .720 & 10.848 .854 & 885.041 .860 & 1.227 .619 .434 \\
\hline
\end{tabular}

\subsection{Accident Costs Up To Official Data}

In Table-8, material damaged accidents and their amount of damage and damage costs, of the years 2011 and 2012, occurred in Turkey, are indicated. The data in 2011 shows that there happened 167.550 traffic accidents with material damage in total and a total of TRL490.507.996 damage cost took place. But, the data of gendarme region belonging to 2011 weren't able to be obtained. Because of this reason, the number and amount of the accidents occurred in that year is thought to be higher than these statistics. When it comes to the evaluation of the data in 2012; it is observed that a total of 195.086 material damaged traffic accidents happened in police region and TRL582.921.231 material damage took place. In addition, it is indicated that, in gendarme region, a total of 13.567 traffic accidents occurred and an amount of TRL180.280.867 material damage was experienced. All the same, when the data of both police and gendarme region are combined, it is seen that a total of 208.653 traffic accidents occurred and a total of TRL763.202.098 material damage emerged.

Table-8: Turkey-wide Material Damaged Traffic Accidents and Their Amount of Damage

\begin{tabular}{|l|r|r|r|r|}
\hline & \multicolumn{2}{|l|}{2011} & \multicolumn{2}{l|}{} \\
\cline { 2 - 5 } & Police & Gendarme & \multicolumn{1}{l|}{ Police } & Gendarme \\
\hline $\begin{array}{l}\text { The Number of Material } \\
\text { Damaged Accidents }\end{array}$ & 167.550 & ------ & 195.086 & 13.567 \\
\hline $\begin{array}{l}\text { Amount of Material Damage } \\
\text { (TRL) }\end{array}$ & 490.507 .996 & ------ & 582.921 .231 & 180.280 .867 \\
\hline
\end{tabular}

Resource: It is prepared by using the data acquired by www.tuik.com, www.trafik.gov.tr

In Turkey, material losses caused by traffic accidents are in fairly high numbers. However; cost accounts of traffic accidents in Turkey can't be carried out correctly. The certified officer investigating the accident notes down conjecturally the amount of damage occurred. And in practice, this amount of damage noted down by certified officer is known to be fairly less than real amount 
(Demiröz, 2006: 10). For this reason, instead of the traffic data recorded by police and gendarme, amount of damage paid by insurance companies are taken into account in this study.

When Table-9 is investigated, it is seen that insurance companies have paid large amounts in order to recover the damage caused by traffic accidents.

Table- 9: Amounts of Damages Paid by Compulsory Traffic Insurance and By Motor Insurance

\begin{tabular}{|l|c|c|r|r|}
\hline Years & \multicolumn{2}{|c|}{ Damage By Compulsory Traffic Insurance } & \multirow{2}{*}{$\begin{array}{c}\text { Damage By Motor } \\
\text { Insurance }\end{array}$} \\
\hline & Material & \multicolumn{1}{|c|}{ Size } & \multicolumn{1}{c}{ Medical Care } & \\
\hline $\mathbf{2 0 0 9}$ & 1930497053 & 168642414 & 90590558 & 2.446 .060 .188 \\
\hline $\mathbf{2 0 1 0}$ & 1360228615 & 217079015 & 149759772 & 2.391 .128 .426 \\
\hline $\mathbf{2 0 1 1}$ & 1519351787 & 345959505 & 87053235 & 2.788 .822 .084 \\
\hline $\mathbf{2 0 1 2}$ (TRL) & 1807221055 & 546356962 & 38077635 & 3.155 .724 .966 \\
\hline $\mathbf{2 0 1 2}$ (\$) & 1.003 .376 .225 & 330.339 .530 & 21.140 .852 & 1.752 .070 .891 \\
\hline
\end{tabular}

Resource: Prepared through the data by http://www.tsb.org.tr/.

Table-10: Total Cost of Traffic Accidents

\begin{tabular}{|c|r|r|r|r|}
\hline & $\begin{array}{r}\text { Compulsory Traffic } \\
\text { Insurance }\end{array}$ & Motor Insurances & Questionnaire & Total \\
\hline $\mathbf{\$}$ & 1.327 .856 .607 & 1.752 .070 .891 & 1.227 .619 .434 & 4.307 .546 .932 \\
\hline Ratio & $\% 30,8$ & $\% 40,7$ & $\% 28,5$ & $\% 100.00$ \\
\hline
\end{tabular}

Resource: Created through Table-9

In Table-9 and Table-10, numeral amounts related to traffic accidents are summed up. Total cost of compulsory traffic insurance is $\$ 1,328$ billion, of motor insurance is $\$ 1,752$ billion. Other cost amount based on the questionnaire is at a level of $\$ 1,227$ billion. Based on this, minimum cost amount in 2012 in Turkey is predicted to be at a level of $\$ 4,307$ billion. The costs falling out of the system account for at least 40,7 percent of costs reflected on the system.

\subsection{The Value of Costs of Accidents for Insurance System}

First of the most important financial function of Insurance Business sector is that, in finance, it provides opportunity for capital accumulation and is a source of saving. The sources people can't put aside to save under normal conditions can turn into savings and thus into investments through insurance system.

Especially in terms of national economies and capital markets, long run reserve saving function can be made real via insurance system and insurance services provided in this sense and financial activities rally thus social welfare level increases. (DPT, 2007: 79).

As can be seen in Table-11, when change in the size of assets for the period 2008-2012/9 in financial sector of Turkey is investigated, it is observed that a constant rise by years has been experienced. When the value of insurance sector within the financial system is investigated, it is 
witnessed that the sector's size of assets acts in a growth parallel to that of financial system. The rates of insurance companies within the total financial system account for $2,3 \%$ in the year 2008 , $2,2 \%$ in $2009,1,9 \%$ in $2010,2 \%$ in $2011,2,2 \%$ in 2012 respectively.

Those rates indicate that insurance sector doesn't possess a significant share within the financial system. However; another indicator to be employed to analyze the value of insurance business sector within the financial system is assurance size provided by insurance sector. By tear of 2009, assurance size provided by insurance sector has been nearly TRL15 Trillion. When we view this amount 15 times as high as gross national product, the significance of insurance system will be understood far better (Yurtseven, 2010: 10).

Table-12 indicates the shares of costs of traffic accidents within insurance system, financial system and GDP respectively.

In insurance system, total loss caused by compulsory traffic insurances and motor insurances is at a level of $\$ 3.079 .927 .498$. These payments account for 11,71 percent of insurance system.

These payments, on the other hand, possess a share of $\% 0,26$ within financial system during the first 9 months of 2012. Payments account for approximately 0,39 percent of GDP which equals $\$ 786.293 .000 .000$ by the end of 2012 .

Based on the study conducted in Uşak, the costs got through are significant enough to be taken into account. These costs possess a rate of 4,66 percent within the insurance system, 0,10 percent within the size of financial system and 0,16 percent within GDP.

Table-11: Size of Assets in Financial System By Years in Turkey

\begin{tabular}{|c|c|c|c|c|c|}
\hline Billion TRL & 2008 & 2009 & 2010 & 2011 & 2012/9 \\
\hline $\begin{array}{l}\text { Central Bank of the Republic of } \\
\text { Turkey (CBT) }\end{array}$ & 113,5 & 110,0 & 128,5 & 146,2 & 188,6 \\
\hline $\begin{array}{ll}\text { Borsa Istanbul } & \text { (BIST) } \\
\text { (Capitalisation) } & \end{array}$ & 182,0 & 350,8 & 472,6 & 381,2 & 507,6 \\
\hline Banks & 732,5 & 834,0 & 1006,0 & 1217,6 & 1308,5 \\
\hline Financial Leasing Corporations & 17,1 & 14,6 & 15,7 & 18,6 & 19,8 \\
\hline Factoring Corporations & 7,8 & 10,4 & 14,5 & 15,7 & 16,3 \\
\hline Consumer Financing Companies & 4,7 & 4,5 & 6,0 & 8,9 & 10,6 \\
\hline Asset Management Corporations & 0,4 & 0,4 & 0,7 & 0,9 & 1,0 \\
\hline Financial Holding Corp. & 5,0 & 4,9 & 5,1 & 5,5 & - \\
\hline Credit Guarantee Fund & 0,1 & 0,1 & 0,1 & 0,2 & - \\
\hline Insurance Companies & 26,5 & 31,5 & 35,1 & 39,9 & 47,4 \\
\hline Reassurance Corporations & 1,4 & 1,6 & 1,6 & 1,6 & - \\
\hline Stok Brokere & 4,2 & 5,2 & 7,5 & 9,6 & - \\
\hline Securities Investment Associations & 0,6 & 0,7 & 0,8 & 0,7 & 0,7 \\
\hline Real Estate Investment Trusts & 4,3 & 4,7 & 17,2 & 18,7 & - \\
\hline
\end{tabular}




\begin{tabular}{|l|r|r|r|r|r|}
\hline Venture Capital Trusts & 0,1 & 0,2 & 0,2 & 0,6 & - \\
\hline $\begin{array}{l}\text { Portfolio Management } \\
\text { Corporations }\end{array}$ & 0,3 & 0,3 & 0,3 & 0,3 & - \\
\hline Mutual Funds & 24,0 & 29,6 & 33,2 & 32,2 & 29,7 \\
\hline Private Pension Funds & 6,0 & 9,1 & 12,0 & 14,1 & 18,4 \\
\hline Total & $\mathbf{1 . 1 3 0 , 5}$ & $\mathbf{1 . 4 1 2 , 9}$ & $\mathbf{1 . 7 5 7 , 1}$ & $\mathbf{1 . 9 1 2 , 5}$ & $\mathbf{2 . 1 4 8 , 7}$ \\
\hline
\end{tabular}

Resource: Banking Regulation and Supervision Agency /Bankacılık Düzenleme ve Denetleme Kurumu (BDDK), "Finansal Piyasalar Raporu”, Eylül 2012

Table-12: The Value of Accident Costs Within Economic Magnitudes

\begin{tabular}{|l|l|c|l|l|}
\hline & Damage Payments & Insurance Sector & Financial System & GDP \\
\hline Official Costs & $\$ 3.079 .927 .498$ & $11,71 \%$ & $0,26 \%$ & $0,39 \%$ \\
\hline Costs out of System & $\$ 1.227 .619 .434$ & $4,66 \%$ & $0.10 \%$ & $0.16 \%$ \\
\hline Total & $\$ 4.307 .546 .932$ & $16,37 \%$ & $0,36 \%$ & $0,55 \%$ \\
\hline
\end{tabular}

Resource: Prepared by us by employing the data of Turkish Statistical Institute (TUIK)

Thus, While the value of traffic accidents within Financial System is $0,36 \%$, the value within GDP turns out to be $0,55 \%$.

Table-13: Compulsory Traffic Insurance Contributions and Damage Payments For 2012

\begin{tabular}{|l|r|r|r|}
\hline & \multicolumn{1}{|c|}{ Contribution } & \multicolumn{1}{c|}{ Payment } & \multicolumn{1}{c|}{ Profit/Loss } \\
\hline Traffic (TRL) & 3.507 .839 .996 & 3.903 .127 .850 & -395.287 .854 \\
\hline Traffic (\$) & 1.947 .566 .539 & 2.167 .031 .907 & -219.465 .368 \\
\hline Personal Accident Insurance (TRL) & 40.389 .077 & 64.365 .695 & -23.976 .618 \\
\hline Traffic (\$) & 22.424 .174 & 35.736 .086 & -13.311 .912 \\
\hline Total (TRL) & 3.548 .229 .073 & 3.967 .493 .545 & -419.264 .472 \\
\hline Total (\$) & 1.969 .990 .713 & 2.202 .767 .993 & -232.777 .280 \\
\hline
\end{tabular}

Resource: Insurance Association of Turkey/Türkiye Sigorta Birliği (TSB)

According to the data of Insurance Association of Turkey, Because of compulsory traffic insurance transactions, insurance companies have generated approximately $\$ 1,97$ billion contribution income and have made $\$ 2,20$ billion indemnity payments. Because of that reason, the loss of the sector caused by these transactions is at a level of $\$ 233$ million. This result has an adverse affect on total profitability of insurance companies and causes them to spend intense effort in other insurance sections in order to make profit.

\section{CONCLUSION}

Transportation system in which transport and shipping activities are carried the most intensely is highway. The biggest problem of such a heavily used highway system is certainly traffic accidents. One of the leading reasons of worldwide deaths, injuries and disablements; traffic accidents, besides such bad events, impose high-level costs on national economies. Turkey is one of the countries that traffic accidents happen most. However, there isn't sufficient study on the matter of determining the nationwide costs of traffic accidents. In this sense, determining costs of accidents with a different approach via this study adjusts to importance of the problem. 
Typically, in classifying the costs of road traffic accidents, direct and indirect cost discrimination is applied (Hejazi et al., 2013; Elvik, 1995; Elvik, 2000; Travén et al., 2002). Direct costs consist of funeral and medical care expenses caused by death and physical injuries, material damages, time loss and administrative expenses. But, such costs are highly difficult to be determined. Material damage can take place in such elements as vehicles, roads, traffic lamps or barriers. It is too difficult to identify the costs created by time loss. Determining the most accurate cost requires great effort. Indirect costs, on the other hand, refer to productivity and efficiency loss, life loss, permanent disablement, psychological damages and socio-economic losses.

This study on determining costs of traffic accidents in Turkey has something in common with many other studies in terms of cost items employed in calculating traffic accident costs. While some studies deal with total costs of road traffic accidents of countries, the others calculate accident costs per capita. Furthermore; some studies, by getting access to records of the patients applying to certain hospitals, pay attention to detecting medical care costs through interview technique. Other studies, on the other hand, aim to determine accident costs in a particular country, on a specific road, in a certain tunnel region. It is seen in some studies that damage and medical costs caused by bicycle and motor bicycle accidents in such countries as Belgium and Vietnam. In all these studies mentioned above, investigations are carried out mostly through official data in the process of acquiring data, whereas investigations based on questionnaire technique are in small number.

In this context, in our study, besides official statistics, research data conducted in the city Uşak are also employed in order to calculate the costs of traffic accidents and it is estimated that the cost of traffic accidents in Turkey for the year 2012 is more than \$4 billion. It is witnessed that insurance companies made a loss of approximately $\$ 233$ million in the year 2012. Total cost of accidents that we found in our study possesses a value of $0,36 \%$ within financial system while a value of $0,55 \%$ within GDP.

When the ratio of determined cost amount of traffic accidents in Turkey by basic financial and economic macro variables is scanned, it is seen that this cost ranks in lower rates compared to the countries mentioned in the literature in the study. However; these countries, the rates of which are given in the study, are mostly underdeveloped or developing ones. It can be said that Turkey, as a developing country, is in a better condition in terms of determined accident costs to national income ratio.

Either the costs of traffic accidents or other insurance losses both lead to reduction of reserves in the hands of insurance companies and limit reserve supply in financial markets. Based on this, such losses are evaluated as non-transferred funds to real sector in economy. Namely, it can be 
said that traffic accidents lead a source having potential to create a production boom to get wasted and introduce an adverse affect on social wealth level. Therefore, such losses may be regarded as funds that can't be exploited with the aim of direct production in economy.

This study, for further periods, can be repeated in a broader sense in a way that it is able to encompass the whole Turkey. Hence, the costs of traffic accidents in Turkey can be determined more realistically. Analyzing the real causes of costs contributes to both understanding more realistic material dimension of accidents and reducing the deaths and injuries by diminishing the number of accidents. Furthermore, the results obtained from the study may be viewed as a means for policy makers to make decisions. 


\section{REFERENCES}

Aertsens J., Geus B., Vandenbulcke G., Degraeuwe B., Broekx S., Nocker L., Liekens I., Mayeres I., Meeusen R., Thomas I., Torfs R., Willems H., Panis L., (2010), “Commuting by Bike in Belgium, the Cost of Minor Accidents", Accident Analysis and Prevention, Vol.42, p.2149-2157.

Alemany R., Ayuso M., Guillén M., (2013), Impact of Road Traffic Injuries on Disability Rates and Long-term Care Cost in Spain", Accident Analysis and Prevention, Vol.60, p. 95-102.

Al-Masaeid, H. R., Al-Mashakbeh, A. A.\& Qudah, A, M., (1999). "Economic Costs of Trafic Accidents in Jordan", Accident and Analysis \& Prevention, 31, 347-357.

Al-shami, H.A., (2008), Determinants of Insurance Companies Profitability in UAE, Master Thesis, College of Business, Universiti Utara Malaysia.

Anh, T., Dao, T., ve Xuan, N. (2005), "The Cost of Road Traffic Accident in Vietnam". Proceedings of the Eastern Asia Society for Transportation Studies. 5, 1923-1933.

Antić B., Vujanić M., Lipovac K., Pešić D., (2011), “Estimation of the Traffic Accidents Costs in Serbia by Using Dominant Costs Model", Transport, Vol, 26 (4), p.433-440.

Bankacılık Düzenleme ve Denetleme Kurumu (BDDK), (2012), Finansal Piyasalar Raporu, Ankara.

Caliendo, C., De Guglielmo ML., (2012), "Accident Rates in Road Tunnels ad Social Cost Evaluation", Procedia-Social and Behaviorial Science, 53, pp. 166-177.

Connelly, L. B. ve Supangan, R. (2006), "The Economic Costs of Road Traffic Crashes: Australia, States and Territories", Accident Analysis and Prevention. 38, 1087-1093.

Demiröz, A. (2006). Kazaların Çevresel ve Teknik Araştırması. Yayımlanmamış Doktora Tezi, Ankara: Gazi Üniversitesi Fen Bilimleri Enstitüsü.

Doğan, M., (2013), Sigorta Şirketlerinin Sermaye Yapısı ile Karlılık Arasındaki İlişki: Türk Sermaye Piyasası Üzerine bir İnceleme", Muhasebe ve Finansman Dergisi, S.57, s.121-136

DPT, (2007), Dokuzuncu Kalkınma Planı, Finansal Hizmetler (Mali Piyasalar, Finans Kurumları, Bankacılık, Sigortacılık), Özel İhtisas Komisyonu Raporu, Yayın No: DPT: 2704, Öí: 659, Ankara.

Elmas G., Yıldızhan B., (1999), "Türkiye'de Ulaşım Politikaları ve Trafik Kazalarının Ekonomik Analizi”, II.Ulaşım ve Trafik Kongresi Bildiri Kitabı, s.268-286, http://arsiv.mmo.org.tr/pdf/11174.pdf, (Access: 05.02.2013)

Elvik, R., Kolbenstvedt, M., Elvebakk, B., Hervik, A., B., (2009), "Costs and Benefits to Sweden of Swedish Road Safety Research", Accident Analysis and Prevention, 41, p. 387-392. 
Elvik, R., (1995), "An Analysis of Official Economic Valuations of Traffic Accident Fatalities in 20 Motorized Countries". Accident Analysis and Prevention, 27( 2), 237-247.

Elvik, R., (2000) "How Much Do Road Accidents Cost the National Economy", Accident and Analysis \& Prevention, Vol.32, p.849-851.

Hejazi R., Shamsudin MN., Radam A., Rahim KA., Ibrahim AZ., Yazdani S., (2013), "Estimation of Traffic Accident Costs: a Prompted Model", International Journal of Injury Control and Safety Promotion, Vol.20, No.2, p.152-157.

İsmail, M.A., Abdelmageed, Samar, M., M., (2010), "Cost of Traffic Accidents in Egypt", World Academy of Science, Engineering and Technology, 42, p. 1308-1314.

López, J., Serrano, P., Duque, B., (2004), "The Economic Costs of Traffic Accidents in Spain", The Journal of Trauma-Injury Infection and Critical Care, Vol. 56 (4), p.883-889.

Malik H., (2011), "Determinants of Insurance Companies Profitability: An Analysis of Insurance Sector of Pakistan", Academic Research International, Vol.1, No.3, p.315-321.

Mareste, P., Persson, U., Berntman, M., (2003), “Long-Term Follow -up and Conequences for Severe Road Traffic Injuries- Treatment Costs and Health Impairment in Sweden in the 1960s and the 1990"', Health Policy, 66, p. 147-158.

Nguyen H., Ivers R.Q., Jan S., Martiniuk A.LC., Li, Q., Pham C., (2013), "The Economic Burden of the Road Traffic Injuries: Evidence from a Provincial General Hospital in Vietnam", Injury Prevention, Vol.19, p.79-84.

Özer, U., (2010), Kasko ve Trafik Sigortaları Karlılık Değerlendirmesi, Reasürör, S. 2010 Nisan, s.7-23.

Öztürk, O., Eken, H., Er, C. (2006), "Motorlu Taşıt Satışlarının Trafik Kazaları Üzerine Olan Etkileri”, Süleyman Demirel Üniversitesi Tıp Fakültesi Dergisi. 13 (4), 12-15.

Pārupa D., Ādamsone L., (2008), "Effectiveness of Public Investment in Road Traffic Accident Prevention Projects, Economics and Business, 7337, p.9-17

Perez, K., Altes, A. G., (2007), "The Economic Cost of Road Traffic Crashes in an Urban Setting", Injury Prevention, 13, p. 65-68.

Pérez-Núñez R., Híjar-Medina M., Heredia-Pi I., Jones S., Silveira-Rodrigues EM., (2010), “Economic Impact of Fatal and Nonfatal Road Traffic Injuries in Belize in 2007", Rev Panam Salud Publica, Vol.28 (5), p.326-336.

Reeddy GMM., Negandhi H., Singh D., Singh A., (2009), "Extent and Determinants of Cost of Road Traffic Injuries in an Indian City", Indian Journal of Medical Sciences, Vol.63, No.12, p.549-556. 
Seninger S., (2010), "Economic Costs of Alcohol-Related Vehicle Crashes in Montana", Montana Business Quarterly/Summer, p.21-24.

Sümer, N., Lajunen, T., Özkan, T., (2002). Sürücü Davranışlarının Kaza Riskindeki Rolü: İhlaller ve Hatalar, Uluslararası 1. Trafik ve Yol Güvenliği Kongresi ve Fuarı, 8-12 Mayıs, Gazi Üniversitesi, Ankara.

Sigortacı Gazetesi, (2013), http://www.sigortacigazetesi.com.tr/manet/5371-kisidusen-sita-prinyada655-turkie-144-dolar.html, (Access: 11.12.2013).

Sweroad, (2001), Türkiye Cumhuriyeti Karayolu İileştirme ve Trafik Güvenliği (KiTGi) Trafik Güvenliği Projesi Ulusal Trafik Güvenliği Programı, Ana Rapor, Ankara.

TUiK, (2012), Karayolu Trafik Kaza Maliyeti 2011, http://www.tuik.gov.tr/Kitap.do?metod= KitapDetay\&KT ID=15\&KITAP ID=70, (Access: 25.07.2013).

Türkiye Sigorta Birliği (TSB) 2012, (2012), Sigorta Sektöründeki Değişim ve Geleceği Şekillendirecek Trendler, http://www.kpmg.com/TR/tr/sektorler/Finansal-hizmetler/Documents/FS-2012de-SigortaSektoru-Mustafa-SU.pdf, (Access: 11.12.2013).

Ünal, T., (1994), Sigorta Sektörünün Ekonomik İşlevi ve Fon Yaratma Kapasitesi, İstanbul Ticaret Odası, Yayın No. 1994-04, İstanbul.

Veisten, K., Sælensminde, K., Alvær, K., Bjørnskau, T., Elvik, R., Schistad, T., Ytterstad, B., (2007). "Total Cost of Bicycle Injuries in Norway: Correcting Injury Figures and Indicating Data Needs", Accident Analysis \& Prevention, 39, p. 1162-1169.

Watkins, K. ve Sridhar, D. (2009), Road Traffic Injuries: The Hidden Development Crisis, A Policy Briefing for the First Global Ministerial Conference on Road Safety, Moscow, 19-20 November.

World Health Organization, (2013a), "Road Traffic Injuries", http://www.who.int/mediacentre/ factsheets/fs358/en/, (Access: 05.12.2013)

World Health Organization, (2013b). Global Status Report on Road Safety: Supporting A Decade of Action, World Health Organization, Geneva.

Yıldırım İ., (2013), "Türk Sigortacılık Sektörünün Yumuşak Karnı: Sigorta Suistimalleri Sorunu”, Sosyal ve Beşeri Bilimler Dergisi, Cilt 5, No.1, s.331-340

Yurtseven, E. (2010), "Sigortacılık Sektöründen Ekonomiye Büyük Destek”, Sigortacı Gazetesi. Kasım 2010.

Zaloshnja, E., Miller, T., Council, F., Persaud, B., (2006), "Crash Costs in the United States by Crash Geometry", Accident Analysis and Prevention, 38, p. 644-651. 
5510 Sayılı Sosyal Sigortalar ve Genel Sağlık Sigortası Kanunu.

$\underline{\text { www.trafik.gov.tr }}$

www.tsb.org.tr/sayfa/2012-yili-trafik-istatistikleri-4-donem (Access: 28.06.2013)

http://en.wikipedia.org/wiki/List of countries by vehicles per capita (Access: 10.02.2013)

http://www.trafik.gov.tr/Sayfalar/Istatistikler/Genel-Kaza.aspx (Access: 28.06.2013)

http://www.tsrsb.org.tr/sayfa/kasko-ve-saglik-analizleri-2011(Access: 15.02.2013)

http://trafikfestivali.usak.edu.tr, Uşak Road Traffic Festival Official WEB Page 